\title{
Education and development factors for social welfare
}

\section{Educación y desarrollo factores para el bienestar social}

\author{
MORALES-BENÍTEZ, Brenda Ivonne†*, MORALES-HERNÁNDEZ, Ramiro and BUDAR- \\ LENDECH, Enrique
}

Universidad Autónoma de Guerrero, Mexico.

ID $1^{\text {st }}$ Author: Brenda Ivonne, Morales-Benítez / ORC ID: 0000-0002-0309-3885

ID $1^{\text {st }}$ Co-author: Ramiro, Morales-Hernández / ORC ID: 0000-0003-0510-8793

ID $2^{\text {nd }}$ Co-author: Enrique, Budar-Lendech / ORC ID: 0000-0001-9808-0974

\begin{abstract}
This article addresses education as one of the factors that limit or encourage the development of regions; the objective is to analyze the relationship between education and development in one of the municipalities of the state of Guerrero, so quantitative methodology tools were used, which led to a diagnosis in the study municipality, as well as statistics from sources. UNDP High Schools, Global Competitiveness Report, Organization for Economic Cooperation and Development, which allowed to frame and identify the level that Mexico saves and therefore the state of Guerrero internationally at the educational levels. The research results reveal low educational levels which has limited development in the municipality.
\end{abstract}

Education, Development, Poverty

\begin{abstract}
Resumen
El artículo aborda la educación como uno de los factores que limitan o propician el desarrollo de las regiones; el objetivo es analizar la relación que existe entre educación y desarrollo en uno de los municipios del estado de Guerrero, se utilizaron herramientas de la metodología cuantitativa lo que consintió levantar un diagnóstico en el municipio de estudio, así también se tomaron estadísticos de fuentes secundarias del PNUD, Global Competitiveness Report, Organization for Economic Cooperation and Development, lo que permitió enmarcar e identificar el nivel que guarda la República Mexicana y por ende el estado de Guerrero a nivel internacional en los niveles educativos. Los resultados de la investigación revelan bajos niveles educativos lo que ha limitado el desarrollo en el municipio.
\end{abstract}

Educación, Desarrollo, Pobreza

Citation: MORALES-BENÍTEZ, Brenda Ivonne, MORALES-HERNÁNDEZ, Ramiro and BUDAR-LENDECH, Enrique. Education and development factors for social welfare. Journal of Social Researches. 2021. 7-19:8-14.

\footnotetext{
* Correspondence to Author (Email: ivonne483@gmail.com)

$\dagger$ Researcher contributing as first author.
} 


\section{Introduction}

Education is one of the parameters that allow societies to observe their development and progress by enriching attitudes, knowledge and values that allow people to empower themselves and actively participate in the decisions that are made in the community, which copes with processes of improvement in families by linking them, this being the generator of development and not an effect or cause of it. Unesco (2013).

The increasing diversification of access to education, especially in the twentieth century, has been perceived as one of the most noticeable characteristics of modern countries (Meyer et al., 1992: 129-149), which is the result of the different strategies that international organizations have been implementing, Strengthening the extension and promotion of education such as the Dakar Global Forum on Education in the Dakar Framework for Action (2000), "Education for All: Our Common Commitments, " however it is relevant to be able to carry out an analysis of the impacts that have been had on Latin American and Caribbean countries in education and above all what has been their consequence in Mexico as a factor of development conditions in the population.

Authors such as Didriksson (2012), Ortega \& Casillas (2013), and Acosta (2014), set out the issue of higher education from the perspective of its evolution, proposals for the future, the quality of teacher performance and taught programs, as well as funding and teaching in research, where Didriksson approaches it from the perspective of Latin America, as the other two authors focus on the country of Mexico.

\section{Global education trends}

The insertion of young people who graduate from their studies into the labour market is a concern that is lived daily in each of the countries, since only those who are better qualified and with sufficient skills manage to put the most in a job, that is why education is not only a problem of the state but a problem that involves the whole of society; according to UNESCO Director Irina Bokova in the introduction of the World Education Monitoring Report 2017-2018, she says that the population is very little involved in education systems by mentioning:
"Everyone has a role to play in improving education. This begins with citizens, with the support of civil society organizations and research institutions, which point to gaps in quality and equitable education".

The importance of assigning better budget ceilings for education is a way to have better technological tools and greater training that allows graduates to strengthen skills and acquire knowledge that responds to the globalized and contemporary world that demands it, leading to better opportunities for citizens.

According to the Annual Global Competitiveness Report 2017-2018" the ranking of the best-educated countries in the world was released (Table 1), which warns of the absence of the countries that make up Latin America and the Caribbean, which leads to a retrospective of the quality of education offered to young people, as well as the commitment for citizens as to their level of well-being.

The evaluation is carried out considering variables such as:

1. The time it takes for people to complete their college education or equivalent.

2. Questions to the social actors (entrepreneurs) of each country, about how much it covers the education provided to graduates in relation to the competitive needs that they demand.

The score ranges from 1 to 7 , where 1 is the lowest parameter and 7 is the highest, with Switzerland and Singapore being observed (in Table 1), that the two countries best assessed and meeting the expectations of the business sectors are Switzerland and Singapore.

\begin{tabular}{|c|c|c|c|c|}
\hline & Country & $\begin{array}{c}\text { Punctuation } \\
\text { 1-7 (best) } \\
2018\end{array}$ & IDH & HDI rating \\
\hline 1 & Switzerland & 6.1 & 0.939 & $\begin{array}{l}\text { Very high } \\
\text { human } \\
\text { development }\end{array}$ \\
\hline 2 & Singapore & 6.1 & 0.925 & $\begin{array}{l}\text { Very high } \\
\text { human } \\
\text { development }\end{array}$ \\
\hline 3 & Finland & 5.9 & 0.895 & $\begin{array}{l}\text { Very high } \\
\text { human } \\
\text { development }\end{array}$ \\
\hline 4 & Netherlands & 5.8 & 0.924 & $\begin{array}{l}\text { Very high } \\
\text { human } \\
\text { developmen }\end{array}$ \\
\hline 5 & $\begin{array}{l}\text { United } \\
\text { States }\end{array}$ & 5.7 & 0.920 & $\begin{array}{l}\text { Very high } \\
\text { human } \\
\text { developmen }\end{array}$ \\
\hline
\end{tabular}

MORALES-BENÍTEZ, Brenda Ivonne, MORALESHERNÁNDEZ, Ramiro and BUDAR-LENDECH, Enrique. Education and development factors for social welfare. Journal of Social Researches. 202 


\begin{tabular}{|r|l|r|r|l|}
\hline 6 & Qatar & 5.7 & 0.856 & $\begin{array}{l}\text { Very high } \\
\text { human } \\
\text { developmen }\end{array}$ \\
\hline 7 & Canada & 5.6 & 0.928 & $\begin{array}{l}\text { Very high } \\
\text { human } \\
\text { developmen }\end{array}$ \\
\hline 8 & $\begin{array}{l}\text { New } \\
\text { Zealand }\end{array}$ & 5.5 & 0.915 & $\begin{array}{l}\text { Very high } \\
\text { human } \\
\text { development }\end{array}$ \\
\hline 9 & $\begin{array}{l}\text { United } \\
\text { Arab } \\
\text { Emirates }\end{array}$ & 5.5 & 0.840 & $\begin{array}{l}\text { Very high } \\
\text { human } \\
\text { development }\end{array}$ \\
\hline 10 & Denmark & 5.4 & 0.925 & $\begin{array}{l}\text { Very high } \\
\text { human } \\
\text { development }\end{array}$ \\
\hline
\end{tabular}

Table 1 Countries with the best quality of education in the world

Source: Own with data del Global Competitiveness Report 2017-2018 y el Informe sobre Desarrollo Humano 2015 2016 PNUD

The ten countries considered to be the best quality of education worldwide in the Global Competitiveness Report, they show very high human development rates, this index created by the United Nations Development Programme (UNDP), determines the level of development that countries in the world have, which allows not only to know the level of economic income of a country's population, but also to assess the state it holds, by providing its citizens with environments where they can develop a better project and living conditions.

Therefore, better education provides for greater opportunities for project development and prosperity conditions, linking that a society with high levels of education tends to achieve better levels of social welfare and economic growth, shortening economic and social inequalities while fostering their strengthening.

\section{Education in Latin America and the Caribbean}

Authors such as Hanushek \& WöBmann (2007) and Dante Canlas (2016) agree that investing in education is essential because it promotes the development of countries, because human capital is a priority factor in strengthening economies and boosting growth, so lack of resources and budget ceilings for this area creates unflattering conditions for their citizens. In Latin America, however, pedagogical entities have many shortcomings.
According to Schwartzman (1999), he acknowledges that educational institutions in Latin America have difficulty responding satisfactorily to the requirements to offer greater access to higher education since governments, despite all the needs that exist, allocate the same resources and in some cases these, tend to be cut down by committing the quality of education, transparency in the functioning and results of them so that education is a component that produces improvement in the lives of citizens of a society and educational progress leads to a development which has a reciprocal relationship (Chabbott and Ramirez, 2006).

Of the countries best evaluated in Latin America and the Caribbean, Costa Rica, Trinidad and Tobago and Jamaica stand out, which are among the top three places with the best educational quality in Latin America and the Caribbean (Table 2). Mexico, on the other hand, ranks ninth only above Peru. Globally, however, they rank 30, 43, 48, 102 and 115 respectively, denoting the gap in opportunities and social welfare of these countries with respect to the former in Table 1.

It can then be a series of deficiencies and lack of development in Latin American and Caribbean countries and therefore a population facing fewer opportunities, greater poverty and poverty, since they do not meet the expectations and demands of the productive and business sectors.

\begin{tabular}{|r|l|r|r|r|l|}
\hline \multicolumn{2}{|c}{ Country } & $\begin{array}{c}\text { World } \\
\text { Ranking }\end{array}$ & $\begin{array}{l}\text { Rating 1 } \\
-\mathbf{7} \text { (best) } \\
\mathbf{2 0 1 8}\end{array}$ & \multicolumn{1}{c|}{ IDH } & \multicolumn{1}{c|}{$\begin{array}{c}\text { Classificati } \\
\text { on }\end{array}$} \\
\hline 1 & Costa Rica & 30 & 4.8 & 0.776 & $\begin{array}{l}\text { High human } \\
\text { development }\end{array}$ \\
\hline 2 & $\begin{array}{l}\text { Trinidad and } \\
\text { Tobago }\end{array}$ & 43 & 4.5 & 0.780 & $\begin{array}{l}\text { High human } \\
\text { development }\end{array}$ \\
\hline 3 & Jamaica & 48 & 4.4 & 0.730 & $\begin{array}{l}\text { High human } \\
\text { development }\end{array}$ \\
\hline 4 & Chile & 62 & 4.1 & 0.847 & $\begin{array}{l}\text { High human } \\
\text { development }\end{array}$ \\
\hline 5 & Uruguay & 73 & 3.9 & 0.795 & $\begin{array}{l}\text { High human } \\
\text { development }\end{array}$ \\
\hline 6 & Colombia & 77 & 3.8 & 0.727 & $\begin{array}{l}\text { High human } \\
\text { development }\end{array}$ \\
\hline 7 & Argentina & 85 & 3.8 & 0.827 & $\begin{array}{l}\text { High human } \\
\text { development }\end{array}$ \\
\hline 8 & Panama & 90 & 3.7 & 0.788 & $\begin{array}{l}\text { High human } \\
\text { development }\end{array}$ \\
\hline 9 & Mexico & 102 & 3.5 & 0.762 & $\begin{array}{l}\text { High human } \\
\text { development }\end{array}$ \\
\hline 10 & Peru & 115 & 3.3 & 0.740 & $\begin{array}{l}\text { High human } \\
\text { development }\end{array}$ \\
\hline
\end{tabular}

Table 2 Top 10 Countries with The Best Quality in Education in Latin America and the Caribbean Source: Own with data del Global Competitiveness Report 2017-2018 y el Informe sobre Desarrollo Humano 2015 2016 PNUD 


\section{Mexico education overview}

According to the Organization for Economic Cooperation and Development (OECD, 2016), the average annual gross income per full-time employee per capita in Mexico is $\$ 15,311$, while the OECD average is $\$ 44,290$ per year, i.e., Mexicans' revenues are 65 percent below comparatively on average with those countries, resulting in a deficit of $\$ 28,979$ per year.

The agency refers that in Mexico there is $64 \%$ in terms of low educational achievement and low grades in the Evaluations of the Programme for International Student Assessment (PISA); In terms of cognitive skills, only thirty-four percent were obtained, considered to be a comparatively high percentage of people suffering from deficiencies.

Likewise, the National Council for the Evaluation of Social Development Policy (CONEVAL 2015) shows figures where poverty has undergone changes in an unscreitionally in the last six years, as shown in Table 3. In 2016, 43.6 percent of the population is in poverty and 50.6 percent have an income below the welfare line. Barceinas (2005) reveals that households where there is a higher level of income are allocated, because heads of households have a high level of education, so it is essential for the author to have higher educational levels in order to have an impact on higher incomes and development in the population, which impacts on poverty reduction and quality of life improvements.

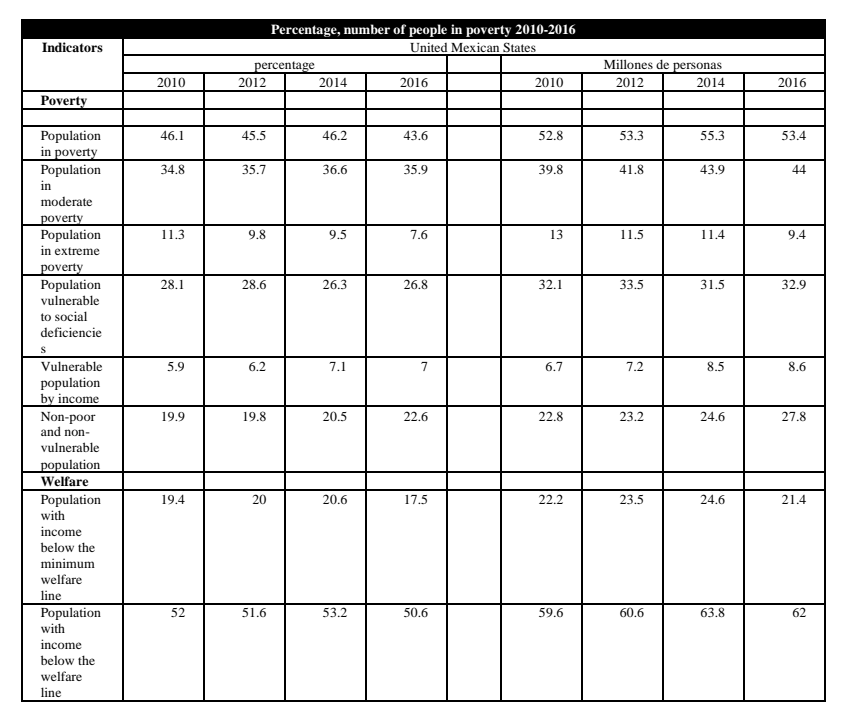

Table 3 U.S. Mexican Poverty Measurement Comparison, 2010 - 2016

Source: Consejo Nacional para la Evaluación de la Política de Desarrollo Social 2015
Paul Krugman (newspaper El Financiero 25 March 2014), Nobel Prize in Economics 2008 , it states that one of the reasons why Mexico's economy remained stagnant for more than 10 years was because of the low level of education, but it also refers to the different economies in this country, indicating that the development of the northern states is superior to the southern states, which causes different Mexico's for citizens and thus the generation of poorer regions compared to others.

It also indicates that this affects greater purchasing power (those in the north), attributing it to the greater education budget in the border strip, which denotes disparities from one region to another and thus opens up a gap in development opportunities and conditions in the country.

\section{Education in Guerrero}

Who was Undersecretary of Higher Education in Mexico, Rodolfo Tuirán at the Newspaper La Jornada (2011), said that in Mexico only 20\% of the most poverty-free young people in the country manage to access higher education, while those with the highest incomes are more likely (four times more) to pursuea college degree, I also assure you that the states with the lowest educational coverage after Querétaro are Chiapas and Oaxaca with 18 percent and Guerrero with 19 percent, which condemns young people to have job insecurity, low productivity and lower income, insufficient level of well-being and poor development, leading to exclusion and marginalization, as well as according to CONAPO 2015 data, the three states of the Mexican Republic with the highest margining rate are Guerrero, Chiapas and Oaxaca.

According to a report by the National Institute of Geography and Statistics (INEGI), corresponding to the second quarter of 2018, $12.5 \%$ of the economically active population works in the primary sector, i.e., 6.7 million Mexicans; In addition, in the states of Oaxaca, Guerrero and Chiapas located in the southeast of the country, it is where a greater population with incomes below five minimum wages is concentrated, which leads to lower well-being and social inequalities. 


\section{Results}

This study was carried out in the municipality of Técpan de Galeana which is located in the Costa Grande region of Guerrero state, where the following points were addressed:

1. Municipal school level.

\section{Certainty in employment.}

3. Monthly income.

One of the guarantees set out in the Political Constitution of the United Mexican States in article 3, it is precisethe right to education and withregard to the educational levels of the municipality it was observed that at the undergraduate level only $2.6 \%$ of the population has it, which means that $97.4 \%$ of citizens lack a professional career, which leads to a very small percentage that can aspire to better working conditions and income. Graphic 1 .

In the municipality of Técpan, the level of education where the population most affects is the primary level, with $43.5 \%$ of people being found to have basic education, so the capacities of the same are lower those who have a higher education (Graphic 1).



Graphic 1 Municipal school level
This is how education in relation to schooling has a significant impact on the individual with regard to job opportunities and income, but not only does it have repercussions individually but also at the regional or local level (Feldman 1998), which limits development in the region because the greater the degree of schooling there is a greater commitment to change social realities and yet in the municipality the main sector of sources of work is the primary sector, so that the secondary sector is developed in a scarce way and in terms of technology and innovation in transformation processes are practically zero.

Barceinas (2005), points out that higher education growth in incomes, better sources of employment and greater development, however, in the municipality the low level of education, has not allowed for development and $97 \%$ of jobs are temporary which leads to job insecurity (Graphic 2).

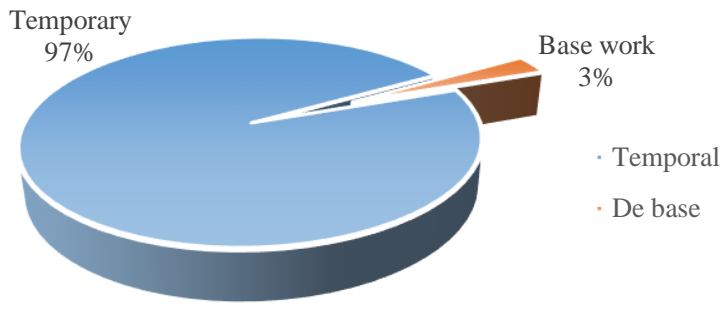

Graphic 2 Certainty in employment

In addition, salaries levied nearly 2 thirds of the municipality (Figure 3) are below the welfare line, which according to CONEVAL in July 2018 was $\$ 2,975.27$ per person and where the monthly minimum wage for the year 2018, in the country is $\$ 2,686.14$ pesos, which leads to virtually zero well-being making the population vulnerable. $^{2}$

\footnotetext{
2 The National Social Development Policy Assessment Council (CONEVAL) is a decentralized public body of the Federal Public Administration, to generate information on the situation of social policy and poverty measurement in Mexico. 
Low educational levels produce productivity income level that does not meet the needs of the wellness line (food, education, housing, transport, health, among others) ${ }^{3}$, resulting in social inequalities, poor and lacking well-being since income is not sufficient for it to meet their needs and the low level of education limits the ability to develop their capacities that allow them to discover new alternatives that improve the quality of life and development in their region (Tuirán (2011).



Graphic 3 Monthly employment income

Thus, in the municipality only $1 \%$ of the population has incomes greater than the four minimum wages (Figure 3), which correspond to the population with a higher academic level, that is, they have a bachelor's degree, confirming what some authors indicate (Barceinas 2005 and Tuirán 2011), noting that education is a change factor that allows better opportunities and entails well-being and development.

\section{Conclusions}

The results of the research reveal the low levels of education that prevail in the Municipality where only $2.6 \%$ of citizens have a bachelor's degree, this causes the opportunity for development in the region and localities to be limited by not counting on the human resource that allows to strengthen the natural resources that it has and to generate the transformation of processes for its development, companies, as well as jobs that consent to greater certainty in them and generate better conditions of wellbeing, in addition to being able to actively participate in decisions to improve and leverage the region's resources

\footnotetext{
3 For more information on the wellness line, see CONEVAL.
}

There is a correlation between education and employment because the better prepared educationally a person is, there is a greater opportunity to obtain better jobs and working conditions.

Having a higher level of education allows for better sources of income, greater opportunities, access to better skilled jobs, but also allows citizens to actively participate and generate their own project proposals according to the strengths that exist in their territory, which leads to greater development and improvement of welfare conditions, so education allows equal opportunities.

However, as noted in the research carried out the higher-level educational levels are minimal in the municipality, so about two-thirds of the study population showed that citizens have lower incomes than those of the welfare line, i.e. the population is in poverty, not meeting the minimum required that CONEVAL marks for a good quality of life which attenuates poverty.

\section{References}

Acosta, A. (2014). "El futuro de la Educación Superior en México" en Revista Iberoamericana de Educación Superior, Volumen 5, Numero 13, pp.91-100.

Barceinas, F. (2005). Educación y distribución del ingreso en México. Sistema de Información de Tendencias Educativas en América Latina (SITEAL). Retrieved March 10, 2016: http://www.siteal.iipe.unesco.org/sites/default/fi les/siteal_debate_3_barceinas_articulo.pdf

Casas, J., \& Barichello, R., (2015). Hacia una Noción sobre la Pobreza. Apuntes del CENES, 34(59), 39-62.

Canlas, D. (2016). Investing in Human Capital for Inclusive Growth: Focus on Hig-her Education en Discussion Paper Series NO. 201602, Philippine Institute for Development Studies. 
Chabbott, C. \& Ramírez, F. (2006). Development and education. En Handbook of the Sociology of Education, M.T. Halliman (ed.), Springer, pp. 163-187

Consejo Nacional de Población (2015), http://www.conapo.gob.mx/es/CONAPO

\section{CONEVAL.}

(2018),

https://www.coneval.org.mx/Medicion/MP/Pag inas/Lineas-de-bienestar-y-canasta-basica.aspx

Coronado S. (25 de marzo 2014), Rezago educativo contribuye a estancamiento: Krugman. El Financiero. Recovered from: Financiero

http://www.elfinanciero.com.mx/sociedad/rezag o-educativo-contribuye-a-estancamientokrugman

Delfin O. (2017), Educación y pobreza en México. Un análisis de eficiencia a nivel estados https://www.researchgate.net/publication/32238 3971_Educacion_y_pobreza_en_Mexico_Un_a nalisis_de_eficiencia_a_nivel_de_estados [accessed Aug 15 2018].

Didricksson, A. (2012). La Nueva Agenda de Transformación de la Educación Superior en América Latina. Perfiles Educativos, XXXIV (138), 184-203.

Feldman, D.C. (1998): Managing Careers in Organizations, Scott-Foresman, Glenview

Forbes México (22 agosto 2018), Sólo 4 de cada 100 mexicanos gana más de 13,000 pesos al mes: Inegi. Forbe. Recovered from: https://www.forbes.com.mx/solo-4-de-cada100-mexicanos-gana-mas-de-13000-pesos-almes-inegi/

Hanushek, E., \& Wößmann, L. (2007). The Role of Education Quality in Economic Growth. Documento de Trabajo de Investigación de Políticas 4122, Banco Mundial, Washington, D.C.

La Jornada. (México2011). Periódico. Sólo 20\% de jóvenes pobres acceden a enseñanza superior lunes 3 de enero de 2011. Available at: http://www.jornada.unam.mx/2011/01/03/ sociedad/029n1soc
Meyer J.W., Ramirez, F.O., Soysal, Y.N. (1992). "World expansion of mass education, 18701980" en Sociology of Education, vol. 65, Numero 2, pp. 128-149

Ortega, J., \& Casillas, M. (2013). Nueva Tendencia de la Educación Superior, la Oferta en Zonas no Metropolitanas. Revista de la educación Superior, XLII:3(167), pp 65-95.

Organization for Economic Cooperation and Development (OCDE). (2017). Como va la vida en México. Retrieved August 17, 2018 from https://www.oecd.org/statistics/Better-Life-

Initiative-country-note-Mexico-in-Espagnol.pdf

UNESCO. (2002). Decenio de las Naciones Unidas de la Educación con miras al Desarrollo Sostenible 2005-2014. Recuperado el 7 de julio de 2018, de http://portal.unesco.org/education/es/ev.phpUR

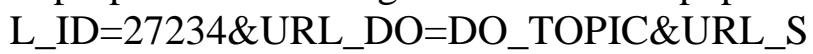
$\mathrm{ECTION}=201 . \mathrm{html}$

UNESCO (Organización de las Naciones Unidas para la Educación, la Ciencia y la Cultura). 2013. Education for All Global Monitoring ReportGirls' Education-The Facts. París

Unesco (2017). Rendir cuentas en el ámbito de la educación. Informe de Seguimiento de la Educación en el Mundo (Informe GEM) 2017/18

PEPPLER BARRY Ulrika (2000). Marco de Acción de Dakar. Foro Mundial de la Educación. UNESCO 2000 Impreso en Francia ED2000/WS/27

Salario Minimo

(2018),

https://salariominimo2018mexico.com/

Schwartzman, Simón. 1999. "Prospects for Higher Education in Latin America". International Higher Education. The Boston College Center for International Higher Education, núm. 17, fall, 9.

Tuiran, R. (2011). La Educación Superior en México: Avances, Rezagos y Retos. Retrieved February $3, \quad 2017$ from: http://online.aliat.edu.mx/adistancia/Calidad/uni dad4/lecturas/TXT_1_S4_EDUC_SUP_AVAN _REZ_RET_TUI-RAN.pd

World Economic Forum; Global Competitiveness 20172018;www.weforum.org/gc

MORALES-BENÍTEZ, Brenda Ivonne, MORALESHERNÁNDEZ, Ramiro and BUDAR-LENDECH, Enrique. Education and development factors for social welfare. Journal of Social Researches. 2021 